\title{
Performance of Chickpea-Mustard Intercropping on Yield and Economics of Chickpea and Mustard Crop under Different Fertility Management and Various Row Combinations
}

\author{
Vipul Singh*, Ghanshyam Singh, Vinay Kumar Pandey, \\ Manoj Kumar and Ajay Singh
}

\begin{abstract}
Department of Agronomy, Narendra Deva University of Agriculture and Technology, Faizabad (U.P.), India
\end{abstract}

*Corresponding author

\section{Keywords}

Chickpea, Mustard, Fertility management, Intercropping and Row combinations

Article Info

Accepted:

xx December 2018

Available Online:

xx Januarv 2019

\section{A B S T R A C T}

A field experiment was carried out at Agronomy Research Farm of Narendra Deva University of Agriculture and Technology, Narendra Nagar (Kumarganj), Faizabad (U.P.) during Rabi season of 2015-16 and 2016-17 to study the effect of fertility management on chickpea-mustard intercropping under various row combinations. Twenty four treatment combinations and consisted of three levels of fertility management (75\% RDF, $100 \% \mathrm{RDF}$ and $125 \%$ RDF for both crops) and eight row combinations of chickpea + mustard (2:1, $4: 1,6: 1,2: 2,4: 2,6: 2$, sole crop of mustard and sole crop of chickpea).The experiment was conducted in Factorial RBD with three replications. The yield components of chickpea \& mustard were maximum under 4:1 (4 row chickpea+ 1 row mustard) row combination in both the consecutive years and among the fertility management $125 \%$ RDF being at par with $100 \%$ RDF during both the consecutive years. The maximum chickpea equivalent yield (CEY) was recorded under the treatment combinations of 4:1 (4 row chickpea +1 row mustard) with $125 \%$ RDF which was significantly superior to overall the treatment during both the years and maximum land equivalent ratio (LER) was obtained at $125 \%$ RDF in a combination of 4:1 (4 row chickpea +1 row mustard) in both the years. Number of seeds plant ${ }^{-1}$ and harvest index in chickpea crop were not influenced significantly due to fertility management and row combinations during both the consecutive years. The highest net return (Rs. $87103 \mathrm{ha}^{-1}$ ) and benefit cost ratio (4.68) were obtained with fertility management $125 \%$ RDF for both crops in a combination of 4:1 (4 row chickpea +1 row mustard) could be most economical.

\section{Introduction}

Chickpea, the third most important pulse crop, plays a vital role in global agricultural economy. In the central and northern region of India, the most commonly grown winter pulse and oilseed crops are chickpea and mustard.
When a legume is grown in association with other crop (intercropping), commonly oilseeds and cereals, the nitrogen nutrition of the associated crop improved by direct nitrogen transfer from legume to oilseed or cereal (Giller and Wilson, 1991). Legume intercrops are also potential sources of plant nutrient that 
compliment/ supplement inorganic fertilizers. In addition, legumes are included in cropping system because they reduce soil erosion (Giller and Cadisch, 1995) and suppress weeds (Exner and Cruse, 1993).

Intercropping utilizes the inter space of widely space crop like mustard and chickpea. Chickpea cultivation with mustard crop augments the production and profitability. Chickpea being legume augment the nitrogen nutrition through nitrogen fixation and consequently improve the soil fertility. Further the production and profitability of mustardchickpea intercropping may be increased through the use of optimum dose of fertilizers. Cereal with legume intercropping is common but the work done so far on oilseed and legume intercropping with a suitable nutrient management and proper crop ratio in merge. Hence, the present study is to be ethiopian mustard/chickpea intercropping system recorded higher mustard equivalent yield over sole mustard and sole chickpea. In intercropping, the values of relative crowding coefficient, AY L, aggressivity, and competitive ratio indicated that the Ethiopian mustard was more competitive than chickpea. In association with mustard + chickpea as inter crop with optimum dose of fertilizers improved the yield of both crops. Tanwar et al. (2011) replied that mustard + chickpea intercropping with ratio of (1:6) and fertilizer with $100 \% \mathrm{RFN}+$ full $\mathrm{P}$ and $\mathrm{K}$ recorded highest yield and net profit. Hence, an experiment was planned to study the production potential of chickpea + mustard intercropping at various row combination at varying fertility levels.

\section{Materials and Methods}

The field experiment was conducted at Agronomy Research Farm, Narendra Deva University of Agriculture and Technology, Narendra Nagar (Kumarganj) Faizabad (U.P.), during Rabi season of 2015-16 and 2016-17.
The soil of experimental field was low in available nitrogen $(203.00$ and $208.00 \mathrm{~kg} / \mathrm{ha})$ and organic carbon $(0.38 \%$ and $0.42 \%)$, medium in available phosphorus (12.25 and $13.20 \mathrm{~kg} / \mathrm{ha}$ ) and high in potassium (265.00 and $267 \mathrm{~kg} / \mathrm{ha}$ ) in Ist and IInd year, respectively. The reaction of the soil was slightly alkaline (7.8). The experiment was laid out in Factorial RBD with three fertility management $(75 \%$ RDF, $100 \%$ RDF and $125 \%$ RDF for both crops) and eight row combinations $(2: 1,4: 1,6: 1,2: 2,4: 2,6: 2$, sole crop of mustard and sole crop of chickpea) with three replication. There were twenty four treatment combinations comprised of 3 fertility management and 8 row combinations. The sowing was done on 25 October in 2015 and 27 October in 2016 with the seed rate of $100 \mathrm{~kg} / \mathrm{ha}$ for chickpea crop and $6 \mathrm{~kg} / \mathrm{ha}$ for mustard crop and spacing between rows was $30 \mathrm{~cm}$ apart. An uniform dose of $100 \mathrm{~kg} \mathrm{P}_{2} \mathrm{O}_{5}$ $\mathrm{ha}^{-1}$ in chickpea and $114 \mathrm{~kg} \mathrm{~N}+125 \mathrm{~kg} \mathrm{P}_{2} \mathrm{O}_{5}$ $+67 \mathrm{~kg} \mathrm{~K}_{2} \mathrm{O} \mathrm{ha}^{-1}$ in mustard was applied to all treatments. Full dose of phosphorus as per treatments and potassium along with half of the nitrogen were applied as basal while remaining half dose of nitrogen was topdressed at first irrigation. Tube-well was the source of irrigation. Irrigations were applied at all critical stages. In order to check the weeds growth one manual weeding was done at 35 days after sowing. The crop was harvested at proper stage of maturity as determined by visual observations on 17 February in 2015 and 19 February in 2016.

\section{Results and Discussion}

\section{Chickpea}

\section{Yield contributing characters}

\section{Number of pods plant ${ }^{-1}$}

A perusal of data in table 1 revealed that the maximum number of pods plant ${ }^{-1}$ recorded in fertilizer $125 \%$ RDF and significantly superior 
over rest of the fertility management during both the years.

Combination of sole chickpea produced significantly higher number of pods plant $^{-1}$ which was at par with $2: 1,4: 1,6: 1,4: 2$ and $6: 2$ and found significant with $2: 2$ chickpea+mustard row combination during both the consecutive years. Interaction effect between fertility management and row combination was not significant.

Higher value of these indices was recorded at $125 \%$ RDF which increased slightly with an increase in levels of fertilizer. This findings are in line of those Abraham et al. (2010), Gokhale et al. (2008), Karwasra and Kumar (2007), Tripathi et al. (2005b), Hossain et al. (2003), and Bhohra and Srivastava (2002).

Number of pods plant $^{-1}$ varied significantly among the row combinations of chickpeamustard intercropping pattern. Among the row ratios in intercropping systems, maximum values of these indices were recorded under sole chickpea which was at par with all row combinations and found significant with $2: 2$ row combination in both the years. This might be due to lesser inter-crop competition, higher photosynthetic active radiation and latent heat available to the crops leading to higher production of photosynthates which together favourably influenced the yield attributing parameters. This finding is in conformity with the results of Kumar and Singh (2006), Kumar et al. (2006), Tripathi et al. (2005b) and Ahlawat et al. (2005a).

\section{Number of seeds plant ${ }^{-1}$}

The data revealed that the number of seeds plant $^{-1}$ was not influenced significantly by fertility management and row combination. Number of seeds plant $^{-1}$ did not vary significantly at different fertility levels in both the years. This findings are in line of those
Abraham et al. (2010), Gokhale et al. (2008), Karwasra and Kumar (2007), Tripathi et al. (2005b), Hossain et al. (2003), and Bhohra and Srivastava (2002).

\section{0-seed weight $(\mathrm{g})$}

The data revealed that the maximum 100-seed weight (g) was recorded with fertilizer $125 \%$ RDF which was at par with $100 \%$ RDF and found significant with $75 \%$ RDF during both the years. However, as regards row combinations, sole chickpea recorded higher test weight being at par with $2: 1,4: 1,6: 1,4: 2$ and 6:2 and significantly superior over $2: 2$ chickpea-mustard intercropping in both the years. Interaction effect between fertility management and row combination was not significant.

Test weight of chickpea influenced significantly at different fertility levels in both the years. Higher value of these indices was recorded at $125 \%$ RDF which increased slightly with an increase in levels of fertilizer. This findings are in line of those Abraham et al. (2010), Gokhale et al. (2008), Karwasra and Kumar (2007), Tripathi et al. (2005b), Hossain et al. (2003), and Bhohra and Srivastava (2002).

Test weight (g) varied significantly among the row combinations of chickpea-mustard intercropping pattern. Among the row ratios in intercropping systems, maximum values of these indices were recorded under sole chickpea which was at par with all row combinations and found significant with 2:2 row combination in both the years. This might be due to lesser inter-crop competition, higher photosynthetic active radiation and latent heat available to the crops leading to higher production of photosynthates which together favourably influenced the yield attributing parameters. This finding is in conformity with the results of Kumar and Singh (2006), Kumar 
et al. (2006), Tripathi et al. (2005b) and Ahlawat et al. (2005a).

\section{Yield characters}

\section{Biological yield (q ha $\left.^{-1}\right)$}

The biological Yield ( $\mathrm{q} \mathrm{ha}^{-1}$ ) influenced significantly by fertility management and row combination. The maximum biological yield was found with $125 \% \mathrm{RDF}$ and significantly superior over rest of the fertility management during both the consecutive years. This might be due to increasing levels of fertilizers to intercrops increases photosynthetic rates and translocation of photosynthate to different plant parts and influenced the yield of intercrops. Abraham et al. (2011), Tripathi et al. (2005b), Bohra and Srivastava (2002), Singh and Verma (1997) and Singh et al. (1998) reported the similar results.

Combination of sole chickpea produced significantly higher biological yield at all the stages of growth which was significantly more than rest combinations of row in both the years. Interaction effect between fertility management and row combination was not significant. Sole chickpea recorded maximum biological yield which was found significantly superior to overall the row combinations in both the years. The result of this investigation also get supported from those obtained by Kumar and Nandan (2007), Kumar and Singh (2006), Kumar et al. (2006), Tripathi et al. (2005b), Ahlawat et al. (2005a) and Thakur et al. (2000).

\section{Seed yield $\left(q\right.$ ha $\left.^{-1}\right)$}

The highest seed yield of $16.72 \mathrm{q} \mathrm{ha}^{-1}$ in first year and $16.99 \mathrm{q} \mathrm{ha}^{-1}$ in second year was obtained with $125 \%$ RDF and significantly superior to other fertility management. However, the lowest seed yield was recorded with $75 \%$ RDF. This might be due to increasing levels of fertilizers to intercrops increases photosynthetic rates and translocation of photosynthate to different plant parts and influenced the yield of intercrops. Abraham et al. (2011), Tripathi et al. (2005b), Bohra and Srivastava (2002), Singh and Verma (1997) and Singh et al. (1998) reported the similar results (Table 2).

Row combination had significant effect on the seed yield. The maximum seed yield was obtained of $18.92 \mathrm{q} \mathrm{ha}^{-1}$ in first year and 19.12 $\mathrm{q} \mathrm{ha}^{-1}$ with sole chickpea which was significantly superior to over all the treatment. However, the lowest seed yield was recorded with $2: 2$ (2 row chickpea +2 row mustard) row combination. The interaction between fertility management and row combination did not influence seed yield significantly.

In the present experiment seed yield of chickpea were highest in their respective sole crop as compare to their intercropping, it was obvious due to more number of plant population in sole than intercropping. The result of this investigation also get supported from those obtained by Kumar and Nandan (2007), Kumar and Singh (2006), Kumar et al. (2006), Tripathi et al. (2005b), Ahlawat et al. (2005a) and Thakur et al. (2000).

\section{Straw yield $\left(\mathbf{q} \mathbf{h a}^{-1}\right)$}

The highest straw yield of $20.75 \mathrm{q} \mathrm{ha}^{-1}$ in first year and $21.07 \mathrm{q} \mathrm{ha}^{-1}$ was obtained with $125 \% \mathrm{RDF}$ and significantly superior to other fertilizers. However, the lowest straw yield was recorded with $75 \%$ RDF fertility management in both the years.

This might be due to increasing levels of fertilizers to intercrops increases photosynthetic rates and translocation of photosynthate to different plant parts and influenced the yield of intercrops. Abraham et al. (2011), Tripathi et al. (2005b), Bohra and 
Srivastava (2002), Singh and Verma (1997) and Singh et al. (1998) reported the similar results.

Row combination had significant effect on the straw yield. The maximum straw yield was obtained of $23.47 \mathrm{q} \mathrm{ha}^{-1}$ in first year and $23.63 \mathrm{q} \mathrm{ha}^{-1}$ with sole chickpea which was significantly superior to overall the treatments. However, the lowest straw yield was recorded with $2: 2$ (2 row chickpea +2 row mustard) during both the years. The interaction effect between fertility management and row combinations was found not significant.

In the present experiment straw yield of chickpea were highest in their respective sole crop as compare to their intercropping, it was obvious due to more number of plant population in sole than intercropping. The result of this investigation also get supported from those obtained by Kumar and Nandan (2007), Kumar and Singh (2006), Kumar et al. (2006), Tripathi et al. (2005b), Ahlawat et al. (2005a) and Thakur et al. (2000).

\section{Harvest index (\%)}

Harvest index was influenced nonsignificantly with fertility management and row combinations during both the years. This might be due to increasing levels of fertilizers to intercrops increases photosynthetic rates and translocation of photosynthate to different plant parts and influenced the yield of intercrops. Abraham et al. (2011), Tripathi et al. (2005b), Bohra and Srivastava (2002), Singh and Verma (1997) and Singh et al. (1998) reported the similar results.

In the present experiment harvest index was not influenced significantly with various row combinations.

The result of this investigation also get supported from those obtained by Kumar and
Nandan (2007), Kumar and Singh (2006), Kumar et al. (2006), Tripathi et al. (2005b), Ahlawat et al. (2005a) and Thakur et al. (2000).

\section{Mustard}

\section{Yield contributing characters}

\section{Number of siliquae plant $^{-1}$}

A perusal of data in table 3 revealed that the maximum number of siliquae plant ${ }^{-1}$ recorded in fertilizer $125 \%$ RDF which was at par with fertilizer $100 \%$ RDF and found significant with fertilizer $75 \%$ RDF during both the years.

Combination of 6:1 chickpea+mustard produced significantly higher number of siliquae plant ${ }^{-1}$ which was at par with $2: 1,4: 1$, $2: 2,4: 2$ and 6:2 row combination and found significant with sole mustard row combination during both the consecutive years. Interaction effect between fertility management and row combination was not significant.

The maximum number of siliquae plant $^{-1}$ of mustard was recorded at $125 \% \mathrm{RDF}$, which was significantly superior to $75 \%$ RDF and at par with $100 \%$ RDF in both the years. This findings are in line of those Abraham et al. (2010), Gokhale et al. (2008), Karwasra and Kumar (2007), Tripathi et al. (2005b), Hossain et al. (2003), and Bhohra and Srivastava (2002).

In the present investigation, maximum value of these indices were recorded under 6:1 row combination which was found at par with all row combination and found significant with sole mustard in both the years.

Similar results were obtained by Kumar and Singh (2006), Tripathi et al., (2005b) and Ahlawat et al. (2005a) also. 


\section{Length of siliquae $(\mathrm{cm})$}

The maximum length of siliquae was noted with the application of $125 \%$ RDF which was at par with $100 \% \mathrm{RDF}$ and found significant with $75 \%$ RDF during both the years.

As regards row combinations of chickpea+mustard intercropping, length of siliquae $(\mathrm{cm})$ increased significantly upto $6: 1$ row combination being at par with $2: 1,4: 1$, $2: 2,4: 2$ and $6: 2$ row combination and found significant with sole mustard row combination in both the consecutive years. Interaction effect was not significant.

In the present investigation, maximum value of these indices were recorded under $6: 1$ row combination which was found at par with all row combination and found significant with sole mustard in both the years. Similar results were obtained by Kumar and Singh (2006), Tripathi et al., (2005b) and Ahlawat et al. (2005a) also.

\section{Number of seeds siliquae ${ }^{-1}$}

The number of seeds siliquae ${ }^{-1}$ influenced by fertility management and row combinations. The maximum number of seeds siliquae ${ }^{-1}$ was found with recommended dose of fertilizer $125 \%$ RDF for both crops which was at par with 100\% RDF and found significant with $75 \%$ RDF during both the consecutive years.

Combination of $6: 1 \quad$ chickpea+mustard intercropping produced significantly higher number of seeds siliquae ${ }^{-1}$ which was at par with $2: 1,4: 1,2: 2,4: 2$ and $6: 2$ row combination and found significant with sole mustard row combination in both the consecutive years.

Interaction effect between fertility management and row combination was not significant.
The maximum number of seeds siliquae $^{-1}$ of mustard was recorded at $125 \%$ RDF, which was significantly superior to $75 \% \mathrm{RDF}$ and at par with $100 \%$ RDF in both the years. This findings are in line of those Abraham et al. (2010), Gokhale et al. (2008), Karwasra and Kumar (2007), Tripathi et al. (2005b), Hossain et al. (2003), and Bhohra and Srivastava (2002).

In the present investigation, maximum value of these indices were recorded under 6:1 row combination which was found at par with all row combination and found significant with sole mustard in both the years. Similar results were obtained by Kumar and Singh (2006), Tripathi et al. (2005b) and Ahlawat et al. (2005a) also.

\section{Test weight (g)}

The data revealed that the maximum test weight (g) was recorded with fertilizer $125 \%$ RDF which was at par with $100 \%$ RDF and found significant with $75 \% \mathrm{RDF}$ during both the years. However, as regards chickpea+mustard row combinations, 6:1 recorded higher test weight being at par with $2: 1,4: 1,2: 2,4: 2$ and $6: 2$ row combination and significantly superior over sole mustard in both the years. Interaction effect between fertility management and row combination was not significant.

Test weight of mustard crop influenced significantly among the different fertility levels in both the years. This findings are in line of those Abraham et al. (2010), Gokhale et al. (2008), Karwasra and Kumar (2007), Tripathi et al. (2005b), Hossain et al. (2003), and Bhohra and Srivastava (2002).

In the present investigation, maximum value of these indices were recorded under 6:1 row combination which was found at par with all row combination and found significant with 
sole mustard in both the years. Similar results were obtained by Kumar and Singh (2006), Tripathi et al. (2005b) and Ahlawat et al. (2005a) also.

\section{Yield characters}

\section{Seed yield $\left(\mathrm{q} \mathrm{ha}^{-1}\right)$}

The highest seed yield of $7.60 \mathrm{q} \mathrm{ha}^{-1}$ in first year and $7.67 \mathrm{q} \mathrm{ha}^{-1}$ in second year was obtained with $125 \%$ RDF and significantly superior to other fertility management. However, the lowest seed yield was recorded with 75\% RDF (Table 4).

Row combination had significant effect on the seed yield. The maximum seed yield was obtained of $14.29 \mathrm{q} \mathrm{ha}^{-1}$ in first year and 14.44 $\mathrm{q} \mathrm{ha}{ }^{-1}$ in second year with sole mustard which was significantly superior to over all the treatment. However, the lowest seed yield was recorded with 6:1 (6 row chickpea +1 row mustard) row combination. The interaction between fertility management and row combination did not influence seed yield significantly.

In mustard maximum seed yield were recorded at $125 \% \mathrm{RDF}$ and significantly scored over $75 \%$ RDF in both the years. This might be due to increasing levels of fertilizers to intercrops increases photosynthetic rates and translocation of photosynthate to different plant parts and influenced the yield of intercrops. Abraham et al. (2011), Tripathi et al. (2005b), Bohra and Srivastava (2002), Singh and Verma (1997) and Singh et al. (1998) reported the similar results.

In the present experiment grain yield of mustard were highest in their respective sole crop as compare to their intercropping, it was obvious due to more number of plant population in sole than intercropping. The result of this investigation also get supported from those obtained by Kumar and Nandan
(2007), Kumar and Singh (2006), Kumar et al. (2006), Tripathi et al. (2005b), Ahlawat et al. (2005a) and Thakur et al. (2000).

\section{Stover yield (q ha $\left.{ }^{-1}\right)$}

The highest stover yield of $23.79 \mathrm{q} \mathrm{ha}^{-1}$ in first year and $31.73 \mathrm{q} \mathrm{ha}^{-1}$ was obtained with $125 \%$ RDF and significantly superior to other fertilizers. However, the lowest stover yield was recorded with $75 \%$ RDF fertility management in both the years.

Row combination had significant effect on the stover yield. The maximum stover yield was obtained of $44.36 \mathrm{q} \mathrm{ha}^{-1}$ in first year and $59.16 \mathrm{q} \mathrm{ha}^{-1}$ with sole mustard which was significantly superior to overall the treatments. However, the lowest straw yield was recorded with 6:1 (6 row chickpea +1 row mustard) during both the years. The interaction effect between fertility management and row combinations was found not significant.

In mustard maximum stover yield were recorded at $125 \% \mathrm{RDF}$ and significantly scored over $75 \%$ RDF in both the years in both the years. This might be due to increasing levels of fertilizers to intercrops increases photosynthetic rates and translocation of photosynthate to different plant parts and influenced the yield of intercrops. Abraham et al. (2011), Tripathi et al. (2005b), Bohra and Srivastava (2002), Singh and Verma (1997) and Singh et al. (1998) reported the similar results.

In the present experiment straw yield of mustard were highest in their respective sole crop as compare to their intercropping, it was obvious due to more number of plant population in sole than intercropping. The result of this investigation also get supported from those obtained by Kumar and Nandan (2007), Kumar and Singh (2006), Kumar et al. (2006), Tripathi et al. (2005b), Ahlawat et al. (2005a) and Thakur et al. (2000) (Table 5). 


\section{Chickpae}

Table.1 Yield contributing characters of chickpea as influenced by different fertility management and various row combinations

\begin{tabular}{|c|c|c|c|}
\hline Treatments & No. of Pods/ Plant & No. of Seeds/ Pod & 100 Seed Weight $(g)$ \\
\hline \multicolumn{4}{|c|}{ Fertilizer management- } \\
\hline F1- 75\% RDF & 58.8 & 1.04 & 17.66 \\
\hline F2- $100 \%$ RDF & 63.3 & 1.07 & 18.15 \\
\hline F3- 125\% RDF & 65.8 & 1.14 & 18.37 \\
\hline S.Em. \pm & 0.65 & 0.05 & 0.15 \\
\hline C.D. $(5 \%)$ & 1.86 & NS & 0.43 \\
\hline \multicolumn{4}{|l|}{ Row combinations- } \\
\hline C1- 2:1 & 61.6 & 1.07 & 17.86 \\
\hline C2- $4: 1$ & 62.8 & 1.09 & 18.04 \\
\hline C3-6:1 & 63.7 & 1.10 & 18.30 \\
\hline C4- 2:2 & 61.1 & 1.06 & 17.75 \\
\hline C5- 4:2 & 62.1 & 1.07 & 17.86 \\
\hline C6- 6:2 & 62.9 & 1.09 & 18.16 \\
\hline C7-Sole Chickpea & 64.2 & 1.11 & 18.45 \\
\hline S.Em. \pm & 0.99 & 0.07 & 0.23 \\
\hline C.D. $(5 \%)$ & 2.84 & NS & 0.66 \\
\hline
\end{tabular}

Table.2 Seed yield $\left(\mathrm{q} \mathrm{ha} \mathrm{a}^{-1}\right)$, straw yield $\left(\mathrm{q} \mathrm{ha} \mathrm{a}^{-1}\right)$, biological yield $\left(\mathrm{q} \mathrm{ha} \mathrm{h}^{-1}\right)$ and harvest index as influenced by different fertility management and various row combinations

\begin{tabular}{|c|c|c|c|c|}
\hline Treatments & $\begin{array}{l}\text { Seed yield (q } \\
\left.\text { ha }^{-1}\right)\end{array}$ & $\begin{array}{c}\text { Straw yield (q } \\
\left.\text { ha }^{-1}\right)\end{array}$ & $\begin{array}{c}\text { Biological yield (q } \\
\left.\text { ha }^{-1}\right)\end{array}$ & $\begin{array}{c}\text { Harvest Index } \\
(\%)\end{array}$ \\
\hline \multicolumn{5}{|c|}{ Fertilizer management- } \\
\hline F1- 75\% RDF & 15.15 & 18.78 & 28.08 & 44.595 \\
\hline F2- $100 \%$ RDF & 16.86 & 20.91 & 33.92 & 44.655 \\
\hline F3- $125 \%$ RDF & 0.24 & 0.58 & 37.765 & 44.62 \\
\hline S.Em. \pm & 0.68 & 0.58 & 0.775 & 0.37 \\
\hline C.D. $(5 \%)$ & 0.68 & 1.65 & 2.215 & NS \\
\hline \multicolumn{5}{|l|}{ Row combinations- } \\
\hline C1- 2:1 & 13.15 & 16.32 & 29.47 & 44.6 \\
\hline C2- 4:1 & 16.50 & 20.49 & 36.99 & 44.605 \\
\hline C3-6:1 & 16.70 & 20.70 & 37.395 & 44.65 \\
\hline C4- 2:2 & 10.49 & 13.04 & 23.525 & 44.595 \\
\hline C5- 4:2 & 13.41 & 16.66 & 30.07 & 44.585 \\
\hline C6- 6:2 & 14.77 & 17.99 & 32.765 & 44.62 \\
\hline C7-Sole Chickpea & 19.02 & 23.55 & 42.57 & 44.675 \\
\hline S.Em. \pm & 0.37 & 0.88 & 1.185 & 0.565 \\
\hline C.D. $(5 \%)$ & 1.04 & 2.52 & 3.385 & NS \\
\hline
\end{tabular}




\section{Mustard}

Table.3 Yield contributing characters of mustard as influenced by different fertility management and various row combinations

\begin{tabular}{|c|c|c|c|c|}
\hline Treatments & $\begin{array}{c}\text { Number of } \\
\text { siliquae plant }\end{array}$ & $\begin{array}{l}\text { Length of } \\
\text { siliquae }(\mathbf{c m})\end{array}$ & $\begin{array}{l}\text { Number of seeds } \\
\text { siliquae }^{-1}\end{array}$ & $\begin{array}{l}\text { 1000-grain } \\
\text { weight }(\mathrm{g})\end{array}$ \\
\hline \multicolumn{5}{|c|}{ Fertility management } \\
\hline F1- 75\% RDF & 225.3 & 5.8 & 10.5 & 4.1 \\
\hline F2- 100\% RDF & 244.8 & 6.1 & 11.0 & 4.2 \\
\hline F3- 125\% RDF & 253.7 & 6.3 & 11.2 & 4.3 \\
\hline S.Em. \pm & 3.45 & 0.09 & 0.14 & 0.06 \\
\hline C.D.(5\%) & 9.85 & 0.26 & 0.39 & 0.16 \\
\hline \multicolumn{5}{|l|}{ Row combinations } \\
\hline C1- 2:1 & 244.5 & 6.1 & 11.0 & 4.2 \\
\hline C2- 4:1 & 246.3 & 6.2 & 11.1 & 4.3 \\
\hline C3-6:1 & 250.0 & 6.3 & 11.3 & 4.3 \\
\hline C4- 2:2 & 236.3 & 5.9 & 10.7 & 4.1 \\
\hline C5- 4:2 & 239.4 & 6.0 & 10.8 & 4.1 \\
\hline C6- 6:2 & 242.1 & 6.1 & 10.9 & 4.2 \\
\hline C7-Sole Mustard & 230.0 & 5.8 & 10.5 & 4.0 \\
\hline S.Em. \pm & 5.27 & 0.14 & 0.21 & 0.09 \\
\hline C.D. $(5 \overline{\%})$ & 15.06 & 0.40 & 0.59 & 0.24 \\
\hline
\end{tabular}

Table.4 Seed yield, stover yield and harvest index as influenced by different fertility management and various row combinations

\begin{tabular}{|c|c|c|c|}
\hline Treatments & Seed yield $\left(\mathbf{q} \mathbf{~ h a}^{-\mathbf{1}}\right)$ & Stover yield $\left(\mathbf{q} \mathbf{~ h a}^{-\mathbf{1}}\right)$ & Harvest Index (\%) \\
\hline Fertility management & \multicolumn{2}{|c|}{} \\
\hline F1- 75\% RDF & 5.0 & 18.5 & 23.78 \\
\hline F2- 100\% RDF & 6.7 & 24.4 & 24.105 \\
\hline F3- 125\% RDF & 7.6 & 27.8 & 24.06 \\
\hline S.Em. \pm & 0.08 & 0.20 & 0.09 \\
\hline C.D.(5\%) & 0.23 & 0.56 & \\
\hline Row combinations & & & 23.855 \\
\hline C1- 2:1 & 5.8 & 21.5 & 24.06 \\
\hline C2- 4:1 & 3.8 & 13.9 & 23.68 \\
\hline C3-6:1 & 2.7 & 10.1 & 24.175 \\
\hline C4- 2:2 & 8.7 & 31.6 & 23.755 \\
\hline C5- 4:2 & 5.5 & 20.5 & 23.97 \\
\hline C6- 6:2 & 4.3 & 15.7 & 0.14 \\
\hline C7-Sole Mustard & 14.4 & 51.8 & 0.39 \\
\hline S.Em. $\mathbf{\pm}$ & 0.13 & 0.30 & \\
\hline C.D.(5\%) & 0.35 & 0.86 & \\
\hline
\end{tabular}


Table.5 Chickpea yield equivalent (CYE) and land equivalent ratio (LER) as influenced by different fertility management and various row combinations

\begin{tabular}{|c|c|c|c|c|}
\hline \multirow[t]{2}{*}{ Treatments } & \multicolumn{2}{|c|}{ Seed Yield (q ha' $\left.{ }^{-1}\right)$} & \multirow[t]{2}{*}{ *CYE (q/ha) } & \multirow[t]{2}{*}{ \#LER } \\
\hline & Chickpea & Mustard & & \\
\hline T1- 75\% RDF- 2:1 & 11.21 & 4.46 & 14.34 & 1.08 \\
\hline T2- 75\% RDF- 4:1 & 13.44 & 2.92 & 15.51 & 1.08 \\
\hline T3 75\% RDF-6:1 & 14.22 & 2.02 & 15.64 & 1.05 \\
\hline T4- 75\% RDF- 2:2 & 8.77 & 6.93 & 13.62 & 1.25 \\
\hline T5- 75\% RDF- 4:2 & 11.62 & 4.24 & 14.64 & 1.09 \\
\hline T6- 75\% RDF- 6:2 & 12.46 & 3.18 & 14.80 & 1.04 \\
\hline T7- 75\% RDF-MUSTARD & 0.00 & 11.28 & 8.57 & 1.00 \\
\hline T8- 75\% RDF- CHICKPEA & 16.43 & 0.00 & 16.43 & 1.00 \\
\hline T9- 100\% RDF- 2:1 & 13.48 & 6.04 & 17.66 & 1.11 \\
\hline T10- 100\% RDF- 4:1 & 16.20 & 3.95 & 18.98 & 1.15 \\
\hline T11-100\% RDF-6:1 & 17.13 & 2.94 & 19.19 & 1.13 \\
\hline T12- 100\% RDF- 2:2 & 10.82 & 9.11 & 17.10 & 1.17 \\
\hline T13- 100\% RDF- 4:2 & 13.77 & 5.75 & 17.77 & 1.12 \\
\hline T14- 100\% RDF- 6:2 & 15.29 & 4.39 & 18.42 & 1.12 \\
\hline T15- 100\% RDF-MUSTARD & 0.00 & 14.77 & 10.99 & 0.92 \\
\hline T16- 100\% RDF- CHICKPEA & 19.32 & 0.00 & 19.32 & 1.08 \\
\hline T17- 125\% RDF- 2:1 & 14.77 & 6.96 & 19.49 & 1.13 \\
\hline T18- 125\% RDF- 4:1 & 19.87 & 4.45 & 22.96 & 1.25 \\
\hline T19-125\% RDF-6:1 & 18.76 & 3.17 & 20.96 & 1.12 \\
\hline T20- 125\% RDF- 2:2 & 11.87 & 10.09 & 18.78 & 1.16 \\
\hline T21- 125\% RDF- 4:2 & 14.86 & 6.52 & 19.33 & 1.11 \\
\hline T22- 125\% RDF- 6:2 & 16.57 & 5.21 & 20.13 & 1.13 \\
\hline T23- 125\% RDF-MUSTARD & 0.00 & 17.04 & 12.40 & 0.96 \\
\hline T24- 125\% RDF- CHICKPEA & 21.32 & 0.00 & 21.32 & 1.07 \\
\hline S.Em \pm & 0.38 & 0.37 & 0.59 & - \\
\hline C.D. $(5 \%)$ & 1.12 & 1.05 & 1.69 & - \\
\hline C.V.(\%) & 6.88 & 6.13 & 6.08 & - \\
\hline
\end{tabular}


Table.6 Economics of various treatment combinations

\begin{tabular}{|l|c|c|c|c|}
\hline \multicolumn{1}{|c|}{ Treatments } & $\begin{array}{c}\text { Cost of cultivation } \\
\text { (Rs/ha) }\end{array}$ & $\begin{array}{c}\text { Gross income } \\
\text { (Rs/ha) }\end{array}$ & $\begin{array}{c}\text { Net income } \\
\text { (Rs/ha) }\end{array}$ & B:C \\
\hline T1- 75\% RDF- 2:1 & 16382 & 65618 & 49236 & 3.01 \\
\hline T2- 75\% RDF- 4:1 & 17102 & 71234 & 54132 & 3.17 \\
\hline T3 75\% RDF-6:1 & 17359 & 72065 & 54706 & 3.15 \\
\hline T4- 75\% RDF- 2:2 & 15559 & 61972 & 46413 & 2.98 \\
\hline T5- 75\% RDF- 4:2 & 16382 & 66846 & 50464 & 3.08 \\
\hline T6- 75\% RDF- 6:2 & 16844 & 67479 & 50635 & 3.01 \\
\hline T7- 75\% RDF-MUSTARD & 12988 & 34722 & 21734 & 1.67 \\
\hline T8- 75\% RDF- CHICKPEA & 18130 & 76070 & 57940 & 3.20 \\
\hline T9- 100\% RDF- 2:1 & 17218 & 81011 & 63793 & 3.71 \\
\hline T10- 100\% RDF- 4:1 & 17849 & 87194 & 69345 & 3.89 \\
\hline T11-100\% RDF-6:1 & 18074 & 88367 & 70293 & 3.89 \\
\hline T12- 100\% RDF- 2:2 & 16497 & 78120 & 61623 & 3.74 \\
\hline T13- 100\% RDF- 4:2 & 17218 & 81430 & 64212 & 3.73 \\
\hline T14- 100\% RDF- 6:2 & 17623 & 84330 & 66707 & 3.79 \\
\hline T15- 100\% RDF- & 14244 & 45448 & 31204 & 2.19 \\
\hline MUSTARD & & & & \\
\hline T16- 100\% RDF- & 18750 & 89472 & 70722 & 3.77 \\
\hline CHICKPEA & 18054 & 89802 & 71748 & 3.97 \\
\hline T17- 125\% RDF- 2:1 & 18596 & 105699 & 87103 & 4.68 \\
\hline T18- 125\% RDF- 4:1 & 18790 & 96641 & 77851 & 4.14 \\
\hline T19-125\% RDF-6:1 & 17435 & 85982 & 68547 & 3.93 \\
\hline T20- 125\% RDF- 2:2 & 18054 & 88897 & 70843 & 3.92 \\
\hline T21- 125\% RDF- 4:2 & 18402 & 92769 & 74367 & 4.04 \\
\hline T22- 125\% RDF- 6:2 & 15500 & 52426 & 36926 & 2.38 \\
\hline T23- 125\% RDF- & 19370 & 98708 & 79338 & 4.10 \\
\hline MUSTARD & & & & \\
\hline T24- 125\% RDF- & & & & \\
\hline
\end{tabular}




\section{Harvest index}

The harvest index influenced significantly by fertility management and row combination. The maximum harvest index was found with $100 \%$ RDF which was at par with $125 \%$ RDF and found significant with $75 \%$ RDF in first year and maximum harvest index was found with $100 \%$ RDF which was at par with $75 \%$ $\mathrm{RDF}$ and $125 \% \mathrm{RDF}$ in second year.

Combination of sole mustard produced significantly higher harvest index which was at par with 4:1 and 2:2 and found significantly superior to rest of the chickpea+mustard row combinations in first year and maximum harvest index was recorded with sole mustard which was at par with 2:2 and 6:2 and significantly superior to rest of the chikpea+mustard row combinations in second year. Interaction effect between fertility management and row combination was not significant.

Harvest index of mustard influenced significantly at different levels of fertilizer in both the years. This might be due to increasing levels of fertilizers to intercrops increases photosynthetic rates and translocation of photosynthate to different plant parts and influenced the yield of intercrops. Abraham et al. (2011), Tripathi et al. (2005b), Bohra and Srivastava (2002), Singh and Verma (1997) and Singh et al. (1998) reported the similar results. The result of this investigation also get supported from those obtained by Kumar and Nandan (2007), Kumar and Singh (2006), Kumar et al. (2006), Tripathi et al. (2005b), Ahlawat et al. (2005a) and Thakur et al. (2000).

\section{Chickpea yield equivalent (CYE) and land equivalent yield (LER)}

In the present investigation, the maximum CYE and LER were recorded at $125 \%$ RDF in a combination of 4:1 chickpea+mustard during both the years of experimentation; differences were found to be significant among the fertility levels in both the years. These findings are in the line of those of Abraham et al. (2011), Srivastava et al. (2007), Tripathi et al. (2005a), Varshney and Arya (2004) and Shrivastava et al. (1996).

In the present investigation, the maximum CYE and LER was recorded in 4:1 row ratio of chickpea + mustard which was found significantly superior to overall the row combinations. The higher CYE and LER ratio in this row ratio of $4: 1$ was as result of increase in seed yield of component crop in intercropping systems with little effect on the yield of main crop. This finding is in close conformity with the result of and Kumar and Nandan (2007), Kumar and Singh (2006), Kumar et al. (2006), Tripathi et al. (2005a), Ali and Mishra (2002) and Pali et al. (1997).

\section{Economics}

In the present investigation gross return, net return and benefit: cost ratio show significant variation among the fertilizer levels in both the years of investigation. Maximum gross return, net return and benefit: cost ratio was recorded under $125 \%$ RDF in both the years. These indices increased with increase in levels of fertilizers up to $125 \% \mathrm{RDF}$, increase in fertilizer levels slightly increased the value of these indices in both the years. This might be due to higher cost involvement in the application of fertilizers at higher fertility level without commensurate increase in the crop yield of the systems. This may have followed the trend of the law of diminishing returns. These results are in close conformity with those of Abraham et al. (2011), Srivastava et al. (2007), Tripathi et al. (2005a), Dubey et al. (2001), Tripathi et al. (1998) and Shrivastava et al. (1996) (Table $6)$. 
Crop production technology not only be technically feasible but it must be economically viable, ecologically sound and sustainable for greater benefit and adoption to the farmers. In the present investigation, maximum gross return, net return and $\mathrm{B}: \mathrm{C}$ ratio were recorded in $4: 1$ row ratio of chickpea + mustard in both the years. These results are in accordance with those of Abraham et al. (2010), Kumar and Singh (2006), Kumar et al. (2006) and Pali et al. (2000).

Thus by raising intercrops not only gives additional yield of intercrop but higher net return can also be generated. In the present investigation mustard has been found to be promising and compatible crop for intercropping with chickpea in 4:1 row ratios, which can increase income considerably without any additional land.

\section{References}

Abraham, T., Sharma, U.C., Thenua, O.V.S and Kumar, B.G.S. (2010). Effect of levels of irrigation and fertility on yield and economics of chickpea (Cicer arietinum) and mustard (Brassica juncea) under sole and intercropping systems. Indian Journal of Agricultural Sciences 80 (5): 372-376.

Abraham, T., Thenua, O.V.S. and Sharma, U.C. (2011). Evaluation performance of chickpea and mustard intercropping system viz.-a-viz. their sole crops as influenced by irrigation regimes and fertility gradients. Indian Journal of Agricultural Sciences 81 (8): 772-775.

Ahlawat, I.P.S., Gangaiah, B and Singh, O. (2005a). Production potential of chickpea (Cicer arietinum) based intercropping systems under irrigated condition. Indian Journal of Agronomy 50 (1): 27-30.

Bohra, J.S. and Srivastava, R.K. (2002).
Studies on sulphur levels and sources at different fertility levels on yields and output-input ratio of Indian mustard. Research on Crops 3 (3): 538-541.

Dubey, M.P. (2001). Response of late-planted linseed (Linum usitatissimum) varieties to nitrogen levels under rain-fed condition. Indian Journal of Agronomy 46 (3): 547-551.

Exner, D.N. and Cruse, R.M. (1993). Interseeded forage legume potential as winter ground cover, nitrogen source, and competition. Journal of Production and Agriculture, 6: 226-231.

Giller, K.E. and Cadisch, G. (1995). Future benefits from biological nitrogen fixation: an ecological approach to agriculture. Plant and Soil, 174: 225277.

Giller, K.E. and Wilson, K.J. (1991). Nitrogen fixation and tropical cropping systems. $\mathrm{CAB}$ International, Wallingford, 10120.

Gokhale, D.N., Wadhvane, S.V., Kalegore, N.K., Khalge, M.L and Shaikh, F.G. (2008). Response of linseed varieties to row spacing and phosphorus levels under irrigated condition. Journal of Oilseed Research 25 (1): 94-95.

Hossain, M.A. (2003). Management of chickpea pod borer, (Helicoverpa armigera) through intercropping and insecticide spraying. Thai Journal of Agricultural Science 36 (1): 51-56.

Karwasra, R.S and Kumar, A. (2007). Response of raya to NPK fertilization under rain-fed condition in Haryana. Haryana Journal of Agronomy 23 (1/2):109-110.

Kumar, A. and Singh, B.P. (2006). Effect of row ratio and phosphorus level on performance of chickpea (Cicer arietinum) + Indian mustard (Brassica juncea) intercropping. Indian Journal of Agronomy 51 (2): 100-102.

Kumar, G. and Nandan, R. (2007). Effect of 
date and pattern of planning on productivity and economics of chickpea + mustard intercropping system. Journal of food legumes 20 92): 184186.

Pali, G.P and Tripathi, R.S. (2000). Performance of linseed varieties under sowing and fertilizer management in rainfed condition. Indian Journals of Agronomy 45 (4): 771-775.

Pali, G.P., Patel, S.R. and Tripathi, R.S. (2000). Intercropping in linseed (Linum usitatissimum) with mustard (Brassica juncea) under rainfed condition of Chhattisgarh region. Indian Journal of Agronomy 45 (3): 540-544.

Pali, G.P., Patel, S.R., Sarkar. C., and Tripathi, R.S. (1997). Performance of linseed (Linum usitatissimum) and gram (Cicer arietinum) intercropping system under rainfed condition of Chhattisgarh region in Madhya Pradesh. Indian Journal of Agronomy 42 (2): 244-246.

Singh, N.B and Verma, K.K. (1997). Response of linseed to varying irrigation and fertility levels. Indian Journal of Agronomy 42 (4): 696-698.

Singh, R.P. and Singh, Y. (1998). Performance of rainfed Indian mustard varieties at varying levels of nitrogen. Indian Journal of Agronomy 43 (4): 709-712.

Srivastava, R.K., Bohra, J.S. and Singh, R.K. (2007).Yields advantage and reciprocity function of Wheat + Indian mustard intercropping under varying row ratios, variety and fertility levels. Indian Journals of Agricultural Sciences 77
(3):139-144.

Tanwar, S.P.S., Rokadia, P. and Singh, A.K. (2011). Effect of row ratio and fertility levels on chickpea (Cicer arietinum L.) and linseed (Linum usitatissimum L.) intercropping system. Indian Journal of Agronomy, 56: 217-222.

Thakur, N.S., Pannase, S.K. and Sharma, R.S. (2000). Production potential of gram (Cicer arietinum)-based intercropping system under rainfed condition. Indian Journal of Agronomy 45 (3): 534-539.

Tripathi, A.K., Lal, J.P., Mishra, R.K. and Dwivedi, R.K. (1998). Effect of fertility levels on production and economics of Rabi oilseed crops in dry land conditions. Bhartia Krishi Anusandhan Patrika 13 (3/4): 157-160.

Tripathi, H.N., Chand, S. and Tripathi, A.K. (2005a). Biological and economical feasibility of chickpea (Cicer arientinum) + Indian mustard (Brassica juncea) cropping systems under varying levels of phosphorus. Indian Journal of Agronomy 50 (1): 31-34.

Tripathi, H.N., Chand, S., Tripathi, A.K. (2005b). Growth and yield of Bengal gram (Cicer arientinum) as influenced by mustard raised as intercrop and varying levels of phosphorus. Research on Crops 6 (2): 205-208.

Varshney, G.J. and Arya, R.L. (2004). Effect of integrated nutrients use and weedcontrol methods on sole gram (Cicer arietinum) and gram + Indian mustard (Brassica juncea) intercropping system. Indian Journal of Agricultural Sciences 74 (3): 121-125.

\section{How to cite this article:}

Vipul Singh, Ghanshyam Singh, Vinay Kumar Pandey, Manoj Kumar and Ajay Singh. 2019. Performance of Chickpea-Mustard Intercropping on Yield and Economics of Chickpea and Mustard Crop under Different Fertility Management and Various Row Combinations. Int.J.Curr.Microbiol.App.Sci. 8(01): 236-249. doi: https://doi.org/10.20546/ijcmas.2019.801.027 